\title{
Analisis Dampak Luas Banjir Pasang Tahun 2020 Terhadap Rencana Pola Ruang Menggunakan Pemodelan Geospasial di Kota Pekalongan Provinsi Jawa Tengah
}

\author{
Ade Firdaus Triagusta*, Agus Anugroho Dwi Suryoputro, Muhammad Helmi, Alfi Satriadi, dan \\ Baskoro Rochaddi
}

Departemen Oseanografi, Jurusan Ilmu Kelautan Fakultas Perikanan dan Ilmu Kelautan Universitas Diponegoro, Jl. Prof.Soedarto, S, Tembalang, Semarang 50275

Email:* adefirdt@gmail.com

\begin{abstract}
Abstrak
Penataan ruang adalah pengaturan susunan ruangan wilayah atau daerah yang bertujuan mewujudkan ruang wilayah yang aman, nyaman, produktif, dan berkelanjutan. Penataan ruang di wilayah pesisir berbeda dengan wilayah lain karena dipengaruhi faktor bahaya dari laut, salah satunya banjir pasang. Banjir pasang merupakan fenomena meluapnya air pasang dari laut ke daratan. Banjir pasang menyebabkan kerugian pada wilayah yang tergenang. Oleh karena itu, penataan ruang wilayah pesisir di masa mendatang haruslah memperhatikan faktor banjir pasang. Tujuan penelitian ini adalah mengetahui tipe pasang surut dan tinggi genangan, membuat model permukaan tanah digital dan mengetahui ketinggian tanah, menganalisis model genangan banjir pasang tahun 2020 dengan validasi model, serta menganalisis dampak luas genangan banjir pasang terhadap Rencana Pola Ruang. Metode yang digunakan untuk mengolah data pasang surut adalah least square, pemodelan permukaan tanah digital dengan InSAR dan pemodelan banjir pasang beserta dampaknya dengan pemodelan geospasial. Hasil penelitian menunjukkan tipe pasang surut adalah tipe campuran condong harian ganda dengan ketinggian genangan sebesar 54,28 cm dan luas genangan banjir pasang sebesar 1.210,183 hektar dengan validasi RMSE tahun 2020 sebesar 0,090. Genangan banjir pasang memberikan dampak hampir ke semua kawasan rencana pola ruang, terutama kawasan peruntukan perumahan kepadatan rendah, perikanan budidaya, dan pertanian tanaman pangan.
\end{abstract}

Kata kunci : Banjir Pasang, Rencana Pola Ruang, Geospasial

\begin{abstract}
Spatial planning is an arrangement of a region or area to create a safe, comfortable, productive, and sustainable regional space. Spatial planning in the coastal area is different from other areas because it is influenced by hazard factors from the sea, including the tidal flood. Tidal flood is a phenomenon of overflowing high tide from the sea to the land. Tidal floods cause losses in inundated areas. Therefore, spatial planning of the coastal area in the future must pay attention to the tidal flood factor. This study aims to find out the type of tidal and inundation height, create digital terrain model and find out the height of the ground, analyze the inundation model of tidal flood in 2020 by validation model, and analyze impacts of tidal flood inundation on the Spatial Pattern. Tidal data processing method using least square, digital terrain model using InSAR, tidal flood model and its impact using geospatial modeling. The results of the study show that the type of tidal is a mixed-mainly semidiurnal tide with inundation height of $54.28 \mathrm{~cm}$ and tidal flood inundation area is 1,210.183 hectares with RSME validation of 0.090. The tidal flood inundation has impacts almost on all areas of the Spatial Pattern Plan, especially the area for low-density housing, aquaculture, and food crop agriculture.
\end{abstract}

Keywords : Tidal Flood, Spatial Pattern Plan, Geospatial

\section{PENDAHULUAN}

Ruang merupakan wadah yang meliputi ruang darat, ruang laut, dan ruang udara, termasuk ruang di dalam bumi sebagai satu kesatuan wilayah, tempat manusia dan makhluk lain hidup, melakukan kegiatan, dan memelihara kelangsungan hidupnya, sedangkan penataan ruang adalah pengaturan susunan ruangan suatu wilayah atau daerah (Priyono, 2016). Tujuan dari penataan ruang adalah mewujudkan ruang wilayah yang aman, nyaman, produktif, dan berkelanjutan berlandaskan terwujudnya keharmonisan antara lingkungan alam dan buatan, keterpaduan dalam penggunaan sumber daya alam dan buatan dengan memperhatikan sumber daya manusia dan pelindungan fungsi ruang dan 
pencegahan dampak negatif terhadap lingkungan akibat pemanfaatan ruang (Jazuli, 2017). Wilayah pesisir merupakan wilayah yang sangat dinamis dengan banyak habitat yang sangat produktif, sehingga menghasilkan berbagai sektor berkomersial tinggi dan menjadikan wilayah pesisir memiliki tingkat populasi yang terus bertambah dengan penggunaan ruang yang sangat kompleks (Yuniastuti, 2016; Sepúlveda et al., 2019). Hal tersebut menyebabkan banyak wilayah pesisir yang memiliki tingkat kerawanan bencana yang tinggi. Salah satu bencana yang sering mengancam wilayah pesisir adalah banjir pasang (Setyati et al., 2018). Salah satu wilayah pesisir yang mengalami fenomena banjir pasang air laut dan terus mengalami peningkatan baik pada frekuensi dan besar luasan tiap tahunnya adalah Kota Pekalongan (Iskandar et al., 2020).

Fenomena banjir pasang air laut di Kota Pekalongan saat ini terjadi semakin parah akibat kenaikan permukaan laut dan penurunan muka tanah (Iskandar et al., 2020). Hal tersebut mengakibatkan kerugian pada masyarakat, menghambat pengembangan wilayah, dan tidak optimalnya pemanfaatan ruang di Kota Pekalongan (Salim, 2018). Padahal, Kota Pekalongan adalah simpul utama dari Kawasan Petanglong (Kabupaten Pekalongan, Kabupaten Batang, dan Kota Pekalongan) yang merupakan kawasan strategis untuk kepentingan pertumbuhan ekonomi dengan sektor unggulan pertanian, pariwisata, industri dan perikanan (Romadhon, 2017; Badriyah et al., 2019). Oleh karena itu, sangat tepat apabila Hakam dan Harsasto (2019) mengungkapkan bahwa penataan ruang wilayah pesisir di masa mendatang haruslah memperhatikan faktor banjir pasang. Berdasarkan analisis tersebut, maka tujuan penelitian ini adalah mengetahui tipe pasang surut dan tinggi genangan, membuat model permukaan tanah digital dan mengetahui ketinggian tanah, menganalisis model genangan banjir pasang tahun 2020 dengan validasi model, serta menganalisis dampak luas genangan banjir pasang terhadap Rencana Pola Ruang.

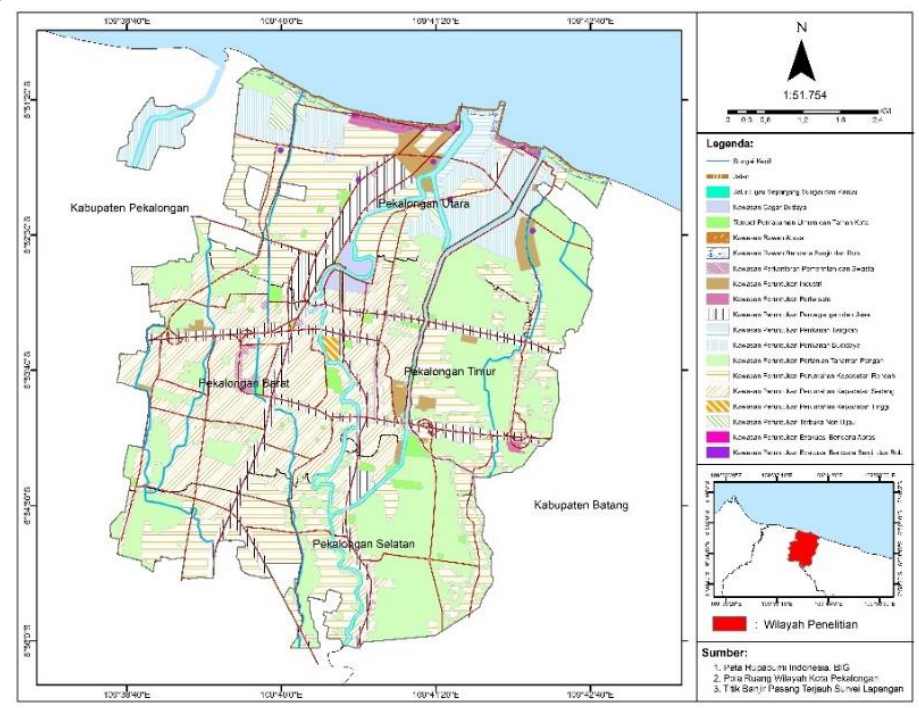

Gambar 1. Peta Wilayah Penelitian

\section{MATERI DAN METODE \\ Materi Penelitian}

Materi yang digunakan pada penelitian ini meliputi data primer dan data sekunder. Data primer yang digunakan yaitu titik banjir pasang terjauh survei lapangan dan titik tinggi muka tanah pesisir Kota Pekalongan survei lapangan MercyCorp, sedangkan data sekunder diantaranya data pasang surut bulan Februari 2020 Badan Informasi Geospasial (BIG), citra SAR Sentinel-1 perekaman 17 Februari 2017 dan 26 Februari 2020, peta raster Rencana Pola Ruang Pemerintah Kota Pekalongan 2009-2029, dan Peta Rupabumi Indonesia digital skala 1:25000.

\section{Metode Penelitian}


Metode yang digunakan pada penelitian ini adalah metode kuantitatif. Metode kuantitatif merupakan metode penelitian yang menggunakan data berupa angka, bersifat sistematis, dan analisis data dilakukan perhitungan statistik atau model. Metode kuantitatif memiliki karakteristik yang sistematis, terencana, dan juga terstruktur dari awal hingga akhir penelitian (Anggito dan Setiawan, 2018). Pada penelitian ini objek yang dikaji adalah dampak banjir pasang tahun 2020 terhadap Rencana Pola Ruang Kota Pekalongan 2009-2029.

Pada penelitian ini dilakukan survei pendahuluan di lokasi penelitian, kemudian pengumpulan data input model banjir pasang, setelah itu dilakukan pengolahan data diantaranya pengolahan data pasang surut, data titik tinggi, pemodelan area banjir, dan dampak luas genangan terhadap rencana pola ruang. Sifat penelitian ini bersifat deskriptif yaitu penelitian yang menjelaskan obyek berdasarkan pada fakta, karakteristik, dan hubungan antara fenomena yang diteliti untuk memecahkan masalah (Rukajat, 2018).

\section{Pengolahan Pasang Surut}

Data pasang surut pengukuran BIG stasiun Pekalongan diolah menggunakan metode Least Square pada program World Tide dengan bantuan software Matrix Laboratory sehingga diperoleh komponen-komponen pasang surut, meliputi amplitudo (A), M2, S2, K1, O1, N2, K2, P1, M1, MS4 (Efendi et al., 2017; Zuhaira et al., 2020). Adapun persamaan-persamaan untuk mendapat nilai elevasi muka air laut dan nilai Formzahl yang juga digunakan pada penelitian Guntara et al. (2017), diantaranya:

1. Mean Sea Level (MSL)

$$
\mathrm{MSL} \quad=\mathrm{A}\left(\mathrm{S}_{0}\right)
$$

2. Lowest Low Water Level (LWL)

$$
\text { LLWL }=\mathrm{A}\left(\mathrm{S}_{0}\right)-\left(\mathrm{A}\left(\mathrm{M}_{2}\right)+\mathrm{A}\left(\mathrm{S}_{2}\right)+\mathrm{A}\left(\mathrm{K}_{1}\right)+\mathrm{A}\left(\mathrm{O}_{1}\right)+\mathrm{A}\left(\mathrm{P}_{1}\right)+\mathrm{A}\left(\mathrm{K}_{2}\right)+\mathrm{A}\left(\mathrm{N}_{2}\right)\right)
$$

3. Highest High Water Level (HHWL)

$$
\mathrm{HHWL}=\mathrm{A}\left(\mathrm{S}_{0}\right)+\left(\mathrm{A}\left(\mathrm{M}_{2}\right)+\mathrm{A}\left(\mathrm{S}_{2}\right)+\mathrm{A}\left(\mathrm{K}_{1}\right)+\mathrm{A}\left(\mathrm{O}_{1}\right)+\mathrm{A}\left(\mathrm{P}_{1}\right)+\mathrm{A}\left(\mathrm{K}_{2}\right)+\mathrm{A}\left(\mathrm{N}_{2}\right)\right)
$$

4. Nilai Formzahl $(\mathrm{F})$

$$
\mathrm{F} \quad=\mathrm{A}\left(\mathrm{K}_{1}\right)+\mathrm{A}\left(\mathrm{O}_{1}\right) / \mathrm{A}\left(\mathrm{M}_{2}\right)+\mathrm{A}\left(\mathrm{S}_{2}\right)
$$

Keterangan :

$\mathrm{S}_{0} \quad$ : Muka air rerata (Mean Sea Level)

$\mathrm{M}_{2} \quad$ : Pasang surut semi diurnal yang dipengaruhi oleh bulan

$\mathrm{S}_{2} \quad$ : Pasang surut semi diurnal yang dipengaruhi oleh matahari

$\mathrm{K}_{2} \quad$ : Pasang surut semi diurnal karena pengaruh perubahan jarak akibat lintasan bulan yang elips

$\mathrm{K}_{1} \quad$ : Pasang surut diurnal karena pengaruh perubahan jarak akibat lintasan bulan yang elips

$\mathrm{O}_{1} \quad$ : Pasang surut diurnal karena yang dipengaruhi yang dipengaruhi oleh bulan

$\mathrm{P}_{1} \quad$ : Pasang surut diurnal karena yang dipengaruhi oleh bulan

A : Amplitudo

Menurut Ongkosongo dan Suyarso (1989) dalam Atmodjo et al., (2019), tipe pasang surut sesuai dengan nilai bilangan Formzahl diklasifikasikan menjadi:

$0,00<\mathrm{F}<0,25=$ Pasang surut ganda beraturan

$0,25<\mathrm{F}<1,50=$ Pasang campuran condong ke harian ganda

$1,50<\mathrm{F}<3,00=$ Pasang campuran condong ke harian tunggal

$\mathrm{F}>3,00 \quad=$ Pasang harian tunggal beraturan

Dalam hal ini untuk mengetahui area genangan banjir pasang maka nilai yang digunakan adalah selisih nilai HHWL dan MSL

\section{Pengolahan Model Permukaan Tanah Digital (Digital Terrain Model)}

Data DEM merupakan data digital berformat raster yang memiliki informasi koordinat posisi $(\mathrm{x}, \mathrm{y})$ dan elevasi (z) pada setiap pixel atau selnya. DTM yang digunakan dalam penelitian ini adalah titik tinggi hasil pengolahan DSM (Digital Surface Model) citra Satelit SAR Sentinel-1 hasil metode InSAR (Interferometric Synthetic Aperture Radar) yang divalidasi dengan data hasil survei lapangan (Sunu et 
al., 2019). Hasil pengolahan data DSM Sentinel-1 diekstrak dengan extract multi values to point dengan data titik tinggi muka tanah pesisir Kota Pekalongan survei lapangan tahun 2020 untuk divalidasi, kemudian elevasinya dimasukkan ke dalam koordinat titik tinggi dan diinterpolasi dengan metode topo to raster. Menurut Nurhendro dan Marfai (2016), topo to raster merupakan proses interpolasi nilai ketinggian untuk setiap piksel raster menggunakan algorithma IDW (Inverse Distance Weighting).

\section{Pemetaan Area Genangan Banjir Pasang}

Pemetaan area genangan banjir pasang digunakan untuk mengetahui luasan dari genangan banjir pasang. Model geospasial genangan banjir pasang dibuat dengan memasukkan nilai selisish HHWL dan MSL ke dalam modul Raster Calculator. Adapun persamaan yang dimasukkan ke dalam modul tersebut seperti yang digunakan oleh Marfai et al. (2011) dalam Iskandar et al. (2020), yaitu:

$$
\begin{aligned}
& \text { WD }=\text { Con }(\text { Con }([D E M] \quad S \text { Elevasi,Elevasi }) \text { Con }[D E M] \quad \text { Elevasi,Elevasi })-[D E M] \\
& \text { Keterangan : } \\
& \text { WD = Keterangan air genangan banjir pasang } \\
& \text { DEM = Data ketinggian tanah } \\
& \text { Elevasi = HHWL - MSL }
\end{aligned}
$$

\section{Penentuan Batas Genangan Banjir Pasang Terjauh}

Penentuan batas genangan banjir pasang terjauh dilakukan dengan menggunakan metode In-depth Interview. Menurut Amin et al. (2021), metode In-depth Interview merupakan proses memperoleh keterangan untuk tujuan penelitian dengan cara tanya jawab sambil bertatap muka antara pewawancara dengan informan atau orang yang diwawancarai, dengan atau tanpa menggunakan pedoman wawancara, pewawancara untuk memperoleh informasi mengenai tiitk genangan banjir pasang terjauh. Survei batas genangan banjir pasang terjauh dilakukan pada 20 titik model yang menunjukkan perubahan titik terjauh genangan cukup signifikan dengan menggunakan Global Positioning System (GPS) untuk menampilkan dan menyimpan titik koordinat.

\section{Analisis Dampak Banjir Pasang terhadap Rencana Pola Ruang}

Analisis dampak banjir pasang tahun 2020 terhadap Rencana Pola Ruang Pemerintah Kota Pekalongan dilakukan untuk mengetahui luas banjir pasang yang menggenangi kawasan dari total luas tiap-tiap jenis kawasan. Analisis ini dilakukan dengan cara overlay dan clip antara model genangan banjir pasang tahun 2020 dengan peta Rencana Pola Ruang Pemerintah Kota Pekalongan 2009-2029. Hasil yang telah didapat kemudian disajikan dalam bentuk peta, tabel, dan grafik perbandingan luas tergenang dari tiap-tiap jenis kawasan.

\section{HASIL DAN PEMBAHASAN}

\section{Karakteristik Pasang Surut}

Hasil pengolahan data pasang surut stasiun BIG Pekalongan menggunakan metode Least Square selama 29 hari pada bulan Februari 2020 didapatkan komponen-komponen harmonik pasang surut berupa nilai amplitudo dan fase, diantaranya sebagai berikut:

Tabel 1. Konstantan Harmonik Pasang Surut

\begin{tabular}{ccc}
\hline Koefisien & $\mathbf{A}(\mathbf{c m})$ & $\mathbf{g}^{\mathbf{0}}$ \\
\hline $\mathrm{S}_{0}$ & 141,41 & 180 \\
\hline $\mathrm{M}_{2}$ & 12,31 & 327,59 \\
\hline $\mathrm{S}_{2}$ & 7.5 & 334,91 \\
\hline $\mathrm{N}_{2}$ & 5,52 & 173,79 \\
\hline $\mathrm{K}_{1}$ & 15,12 & 237,38 \\
\hline $\mathrm{O}_{1}$ & 3,15 & 325,17 \\
\hline
\end{tabular}




\begin{tabular}{ccc}
\hline Koefisien & $\mathbf{A}(\mathbf{c m})$ & $\mathbf{g}^{\mathbf{0}}$ \\
\hline $\mathrm{M}_{4}$ & 0,73 & 71,14 \\
\hline $\mathrm{MS}_{4}$ & 0,52 & 350,45 \\
\hline $\mathrm{K}_{2}$ & 1,95 & 192,09 \\
\hline $\mathrm{P}_{1}$ & 14,26 & 279,39 \\
\hline
\end{tabular}

Nilai Formzahl hasil pengolahan sebesar 0,92, sehingga tipe pasang surut di perairan Kota Pekalongan adalah pasang campuran condong ke harian ganda (mixed tide, prevailing semidiurnal). Hasil tipe pasang surut tersebut sama dengan penelitian sebelumnya yang dilakukan oleh Febriani et al. (2017) dan Iskandar et al. (2020) di Kota Pekalongan yang juga memperoleh hasil tipe pasang surut campuran condong ke harian ganda. Hal tersebut berarti pasang surut di Kota Pekalongan terjadi dua kali pasang dan dua kali surut dalam 24 jam namun dengan tinggi dan periode yang berbeda (Hasanudin et al., 2016; Syamsudin et al., 2019; dan Prayogo, 2021). Selain itu, didapat juga nilai HHWL dan MSL berturut-turut sebesar 195,69 $\mathrm{cm}$ dan $141,41 \mathrm{~cm}$. Berdasarkan nilai tersebut, maka dapat dihitung tinggi genangan dengan mencari selisih antara nilai HHWL dengan MSL yaitu sebesar 54,28 cm.

\section{Model Permukaan Tanah Digital (Digital Terrain Model)}

Data digital terrain model didapat dari hasil pengolahan citra SAR sentinel-1 menggunakan metode InSAR. Ketinggian tanah Kota Pekalogan sangat bervariasi dengan rentang ketinggian 0 sampai 11,017 meter, terdapat 4 kecamatan yang ada di Kota Pekalongan. Wilayah bagian selatan cenderung memiliki ketinggian yang tinggi dibandingkan dengan daerah sebelah utara, sehingga semakin ke arah selatan maka semakin tinggi pula ketinggian tanah pada wilayah tersebut. Rentang nilai ketinggian tanah tiap kecamatan, sebagai berikut:

Tabel 2. Ketinggian Tanah Tiap Kecamatan Tahun 2020 di Kota Pekalongan

\begin{tabular}{clc}
\hline No & \multicolumn{1}{c}{ Kecamatan } & Elevasi (meter) \\
\hline 1 & Pekalongan Utara & $0-3,062$ \\
2 & Pekalongan Barat & $0,189-7,961$ \\
3 & Pekalongan Timur & $0,346-10,862$ \\
4 & Pekalongan Selatan & $5,022-11,017$ \\
\hline
\end{tabular}

Tinggi tanah Kota Pekalongan tersebut kemudian divalidasi menggunakan data titik tinggi muka tanah pesisir Kota Pekalongan hasil survei lapangan pada Februari 2020. Hasil validasi didapat dengan hasil nilai RMSE sebesar 0,467. Hal tersebut berarti akurasi model dengan hasil survei berkisar 46,7 $\mathrm{cm}$. 


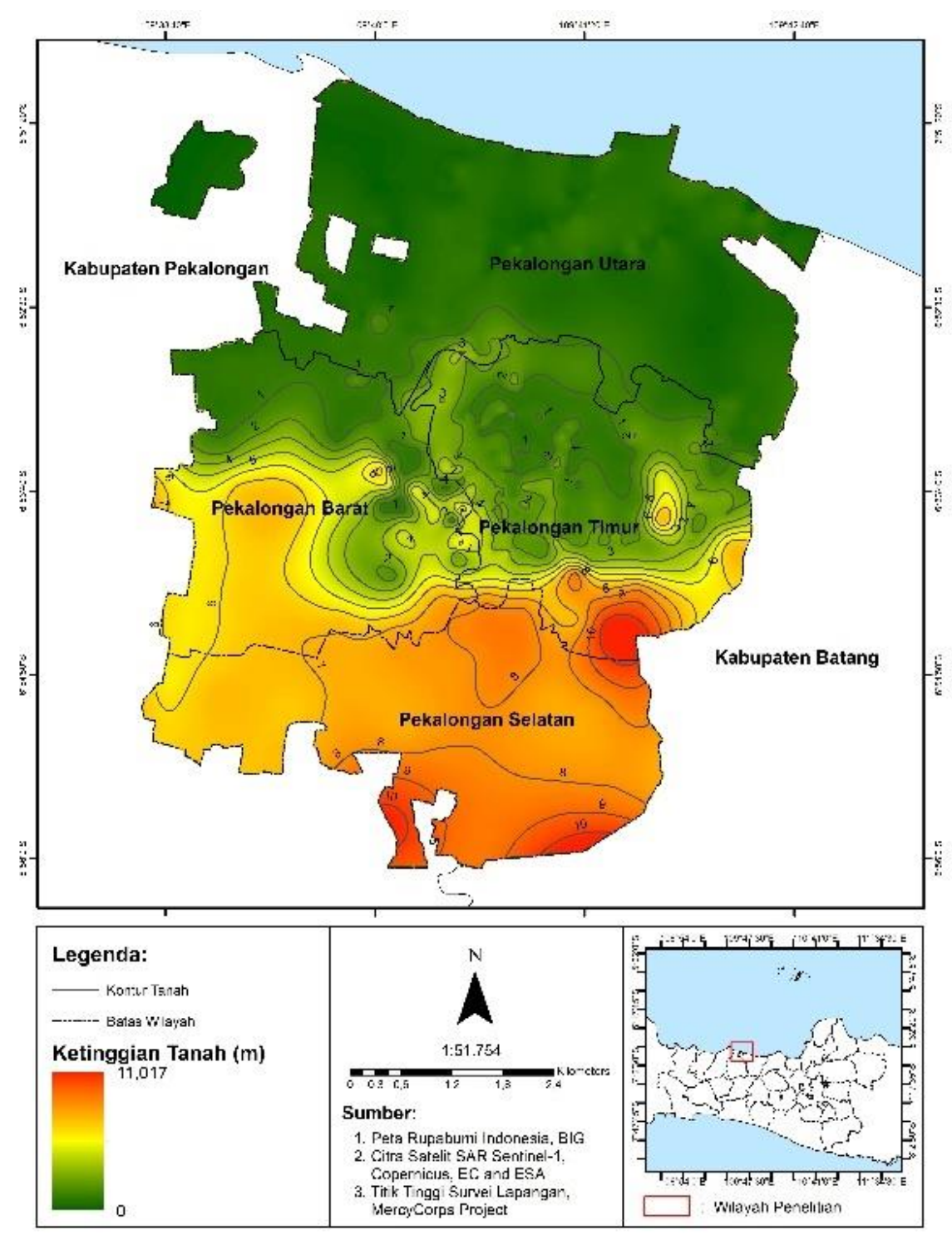

Gambar 1. Ketinggian Tanah Kota Pekalongan

Menurut penelitian Marfai et al. (2013), elevasi pesisir Pekalongan berkisar antara 0 hingga 11,02 meter, sedangkan penelitian lainnya dari Iskandar et al. (2020), elevasi muka tanah Kota Pekalongan berkisar antara 0 hingga 12,74 meter. Perbedaan ketinggian pada penelitian ini berbeda dikarenakan nilai koherensi pasangan citra SAR sentinel-1. Hal ini diperkuat oleh Sunu etial., (2019) menyatakan bahwa gelombang C0Band yang dibawa oleh satelit SAR sentinel-1 tidak dapat dipantulkan dengan baik di daerah dengan vegetasi tinggi dan daerah yang tersaturasi air. Daerah yang memiliki perbedaan paling rendah pada daerah pemukiman. Hal ini disebabkan karena daerah pemukiman tidak banyak terjadi perubahan dan menghasilkan nilai koherensi yang tinggi pada pasangan citra radar. 


\section{Luas Genangan Banjir Pasang Tahun 2020 pada Rencana Pola Ruang}

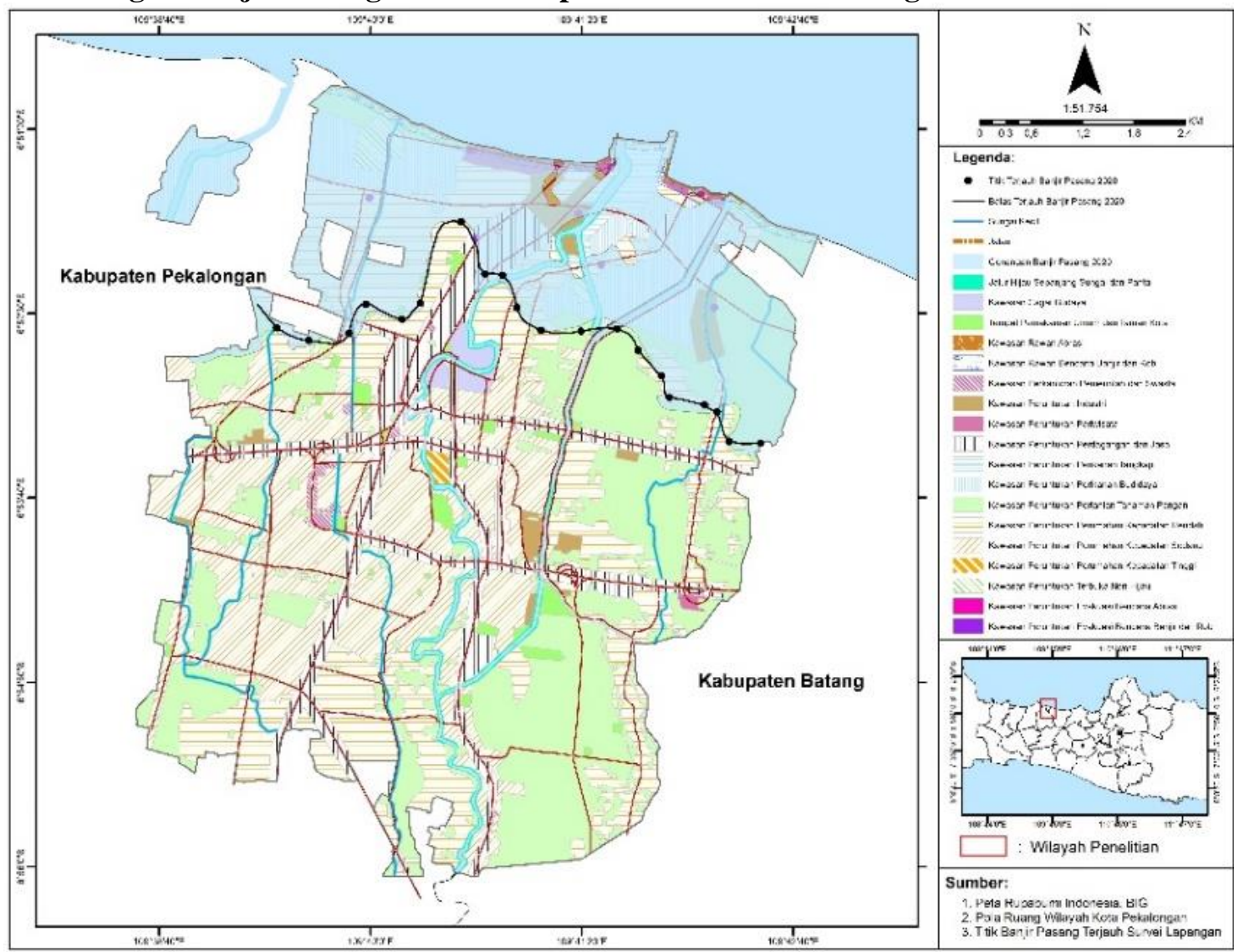

Gambar 2. Luas Genangan Banjir Pasang Tahun 2020 pada Rencana Pola Ruang

Genangan banjir pasang tahun 2020 dimodelkan dengan tinggi genangan sebesar 54,28 cm dan ketinggian tanah berkisar antara $0-11,017 \mathrm{~m}$. Kawasan-kawasan yang memiliki ketinggian tanah kurang dari 54,28 cm akan tergenang banjir pasang, sehingga didapat luas kawasan yang tergenang banjir pasang seluas 1.210,183 hektar. Kawasan tergenang banjir pasang ditunjukkan pada gambar 7, sedangkan lima kawasan yang mengalami dampak terbesar yaitu kawasan peruntukan perumahan kepadatan rendah, kawasan peruntukan perikanan budidaya, kawasan peruntukan pertanian tanaman pangan, kawasan peruntukan perdagangan dan jasa, dan kawasan peruntukan industri dengan luas berturut-turut sebesar 326,545 hektar, 310,907 hektar, 256,351 hektar, 54,110 hektar, dan 49,899 hektar. Hal ini dikarenakan kawasan-kawasan tersebut mendominasi wilayah Kecamatan Pekalongan Utara sehingga mendapat dampak terbesar akibat banjir pasang pula. Adapun rincian luas terdampak masingmasing kawasan pola ruang wilayah di Kota Pekalongan yang terkena banjir pasang ditunjukkan pada Tabel 4.

\section{Hasil Survei Lokasi Titik Genangan Banjir Pasang Terjauh}

Titik lokasi genangan banjir pasang terjauh didapat dari wawancara mendalam (In Depth Interview) yang lakukan pada lokasi-lokasi yang terkena genangan banjir pasang hasil pemodelan tahun 2020. Sebanyak 20 titik didapatkan untuk melakukan validasi model dan melihat akurasi hasil pemodelan. Berdasarkan hasil validasi menggunakan metode RootiiMean Square Error (RMSE), didapatkan nilai RMSE sebesari0,090. Hal tersebut berarti akurasi model genangan dengan hasil survei lapangan berkisar $0,09 \mathrm{~m}$. Adapun lokasi survei titik banjir pasang terjauh, sebagai berikut: 
Tabel 3. Lokasi Survei Titik Banjir Pasang Terjauh Kota Pekalongan

\begin{tabular}{cccl}
\hline No & Longitude & Latitude & \multicolumn{1}{c}{ Kawasan Rencana Pola Ruang } \\
\hline 1 & $-6,8886791$ & 109,7077072 & Pertanian Tanaman Pangan \\
2 & $-6,8884908$ & 109,7043738 & Pertanian Tanaman Pangan \\
3 & $-6,8854003$ & 109,7031116 & Perumahan Kepadatan Rendah \\
4 & $-6,8846673$ & 109,7018261 & Perumahan Kepadatan Rendah \\
5 & $-6,8838510$ & 109,6980790 & Perumahan Kepadatan Rendah \\
6 & $-6,8815801$ & 109,6972821 & Perumahan Kepadatan Rendah \\
7 & $-6,8788879$ & 109,6948045 & Pertanian Tanaman Pangan \\
8 & $-6,8766250$ & 109,6925858 & Pertanian Tanaman Pangan \\
9 & $-6,8768797$ & 109,6888035 & Pertanian Tanaman Pangan \\
10 & $-6,8768211$ & 109,6846118 & Perumahan Kepadatan Rendah \\
11 & $-6,8743649$ & 109,6820487 & Perumahan Kepadatan Rendah \\
12 & $-6,8709754$ & 109,6805242 & Perdagangan dan Jasa \\
13 & $-6,8708379$ & 109,6786564 & Perdagangan dan Jasa \\
14 & $-6,8653337$ & 109,6761885 & Perumahan Kepadatan Rendah \\
15 & $-6,8739103$ & 109,6719018 & Perumahan Kepadatan Rendah \\
16 & $-6,8756044$ & 109,6699645 & Pemakaman Umum dan Taman Kota \\
17 & $-6,8740474$ & 109,6661832 & Perumahan Kepadatan Rendah \\
18 & $-6,8770981$ & 109,6644027 & Perumahan Kepadatan Rendah \\
19 & $-6,8778470$ & 109,6601649 & Pertanian Tanaman Pangan \\
20 & $-6,8765110$ & 109,6567608 & Perumahan Kepadatan Rendah \\
\hline
\end{tabular}

\section{Dampak Banjir Pasang Tahun 2020 terhadap Rencana Pola Ruang}

Berdasarkan luas genangan sebesar 1.210,183 hektar, didapatkan bahwa genangan banjir pasang memberikan dampak hampir ke semua kawasan pada Rencana Pola Ruang Kota Pekalongan, kecuali pada kawasan peruntukan perumahan kepadatan tinggi dan kawasan cagar budaya. Rencana Pola Ruang sendiri terbagi menjadi dua kategori kawasan yaitu kawasan lindung dan kawasan budidaya. Pada Peraturan Daerah Rencana Tata Ruang Wilayah Kota Pekalongan disebutkan bahwa kawasan lindung adalah wilayah yang ditetapkan dengan fungsi utama melindungi kelestarian lingkungan hidup yang mencakup sumber daya alam dan sumber daya buatan, sedangkan kawasan budidaya adalah wilayah yang ditetapkan dengan fungsi utama untuk dibudidayakan atas dasar kondisi dan potensi sumber daya alam, sumber daya manusia dan sumber daya buatan.

Kawasan lindung memiliki beberapa peruntukan, diantaranya kawasan perlindungan setempat (jalur hijau sepanjang sungai dan pantai), kawasan cagar budaya, kawasan ruang terbuka hijau (tempat pemakaman umum dan taman kota), kawasan rawan rawan bencana abrasi, dan kawasan rawan bencana banjir dan pasang. Banjir pasang tahun 2020 memberikan dampak hampir ke seluruh kawasan lindung di Kecamatan Pekalongan Utara, kecuali pada kawasan peruntukan cagar budaya. Hal tersebut disebabkan kawasan peruntukan cagar budaya yang berada Kecamatan Pekalongan Utara hanyalah sebagian saja dan lokasinya berada pada ujung bagian selatan kecamatan yang tidak terkena banjir pasang terjauh tahun 2020.

Kawasan budidaya juga memiliki beberapa peruntukan, diantaranya kawasan perkantoran dan swasta, kawasan peruntukan industri, kawasan peruntukan pariwisata, kawasan peruntukan perdagangan dan jasa, kawasan peruntukan perikanan tangkap, kawasan peruntukan perikanan budidaya, kawasan 
peruntukan pertanian tanaman pangan, kawasan peruntukan perumahan kepadatan rendah, kawasan peruntukan perumahan kepadatan sedang, kawasan peruntukan perumahan kepadatan tinggi, kawasan peruntukan terbuka non hijau, kawasan peruntukan evakuasi bencana abrasi, dan kawasan peruntukan evakuasi bencana banjir dan pasang. Banjir pasang tahun 2020 memberikan dampak hampir ke seluruh kawasan lindung di Kecamatan Pekalongan Utara, kecuali pada kawasan peruntukan perumahan kepadatan tinggi. Hal tersebut disebabkan kawasan peruntukan perumahan kepadatan tinggi hanya berada pada wilayah tengah kota yang jaraknya cukup jauh dari banjir pasang terjauh tahun 2020 .

Tabel 4. Luas Kawasan Terdampak Banjir Pasang di Kota Pekalongan Tahun 2020-2029

\begin{tabular}{|c|l|c|}
\hline \multicolumn{2}{|c|}{ Kawasan Pola Ruang Wilayah } & Luas Terdampak (ha) \\
\hline \multicolumn{2}{|c|}{ Kawasan Lindung } \\
\hline \multicolumn{2}{|c|}{ Kawasan Perlindungan Setempat } \\
\hline 1 & Jalur Hijau Sepanjang Sungai dan Pantai \\
\hline \multicolumn{2}{|c|}{ Kawasan Cagar Budaya } \\
\hline 2 & Kawasan Cagar Budaya \\
\hline Kawasan Ruang Terbuka Hijau \\
\hline 3 & Tempat Pemakaman Umum dan Taman Kota \\
\hline Kawasan Rawan Bencana & 0,000 \\
\hline 4 & Kawasan Rawan Abrasi \\
\hline 5 & Kawasan Rawan Bencana Banjir dan Pasang \\
\hline \multicolumn{2}{|c|}{ Kawan Budidaya } \\
\hline 1 & Kawasan Perkantoran Pemerintah dan Swasta \\
\hline 2 & Kawasan Peruntukan Industri \\
\hline 3 & Kawasan Peruntukan Pariwisata & 13,028 \\
\hline 4 & Kawasan Peruntukan Perdagangan dan Jasa & 57,069 \\
\hline 5 & Kawasan Peruntukan Perikanan Tangkap & 0,743 \\
\hline 6 & Kawasan Peruntukan Perikanan Budidaya & 49,899 \\
\hline 7 & Kawasan Peruntukan Pertanian Tanaman Pangan & 22,757 \\
\hline 8 & Kawasan Peruntukan Perumahan Kepadatan Rendah & 54,110 \\
\hline 9 & Kawasan Peruntukan Perumahan Kepadatan Sedang & 41,927 \\
\hline 10 & Kawasan Peruntukan Perumahan Kepadatan Tinggi & 310,907 \\
\hline 11 & Kawasan Peruntukan Terbuka Non Hijau & 256,351 \\
\hline 12 & Kawasan Peruntukan Evakuasi Bencana Abrasi & 2,895 \\
\hline 13 & Kawasan Peruntukan Evakuasi Bencana Banjir dan Pasang & 0,000 \\
\hline
\end{tabular}

Berdasarkan hasil perhitungan luas kawasan terdampak, didapatlah perbandingan luas terdampak masing-masing wilayah rencana pola ruang di Kota Pekalongan yang ditunjukkan pada Gambar 3. 


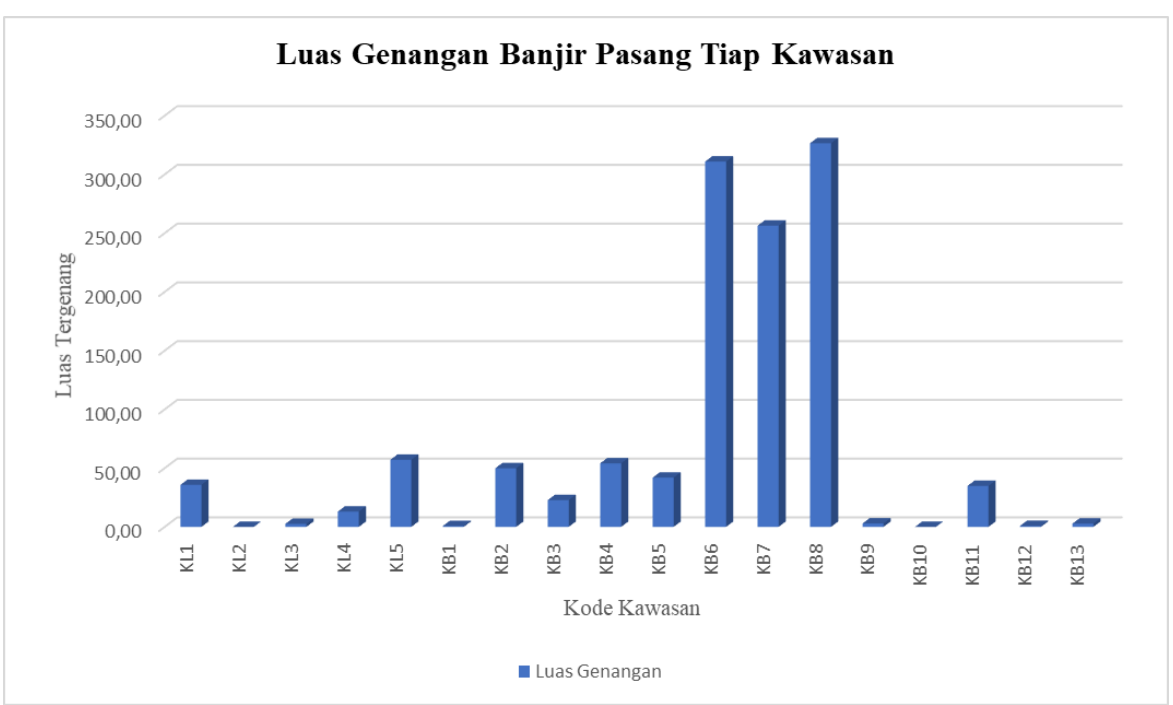

Gambar 3. Grafik Luas Genangan Banjir Pasang Tiap Kawasan di Kota Pekalongan

Keterangan:

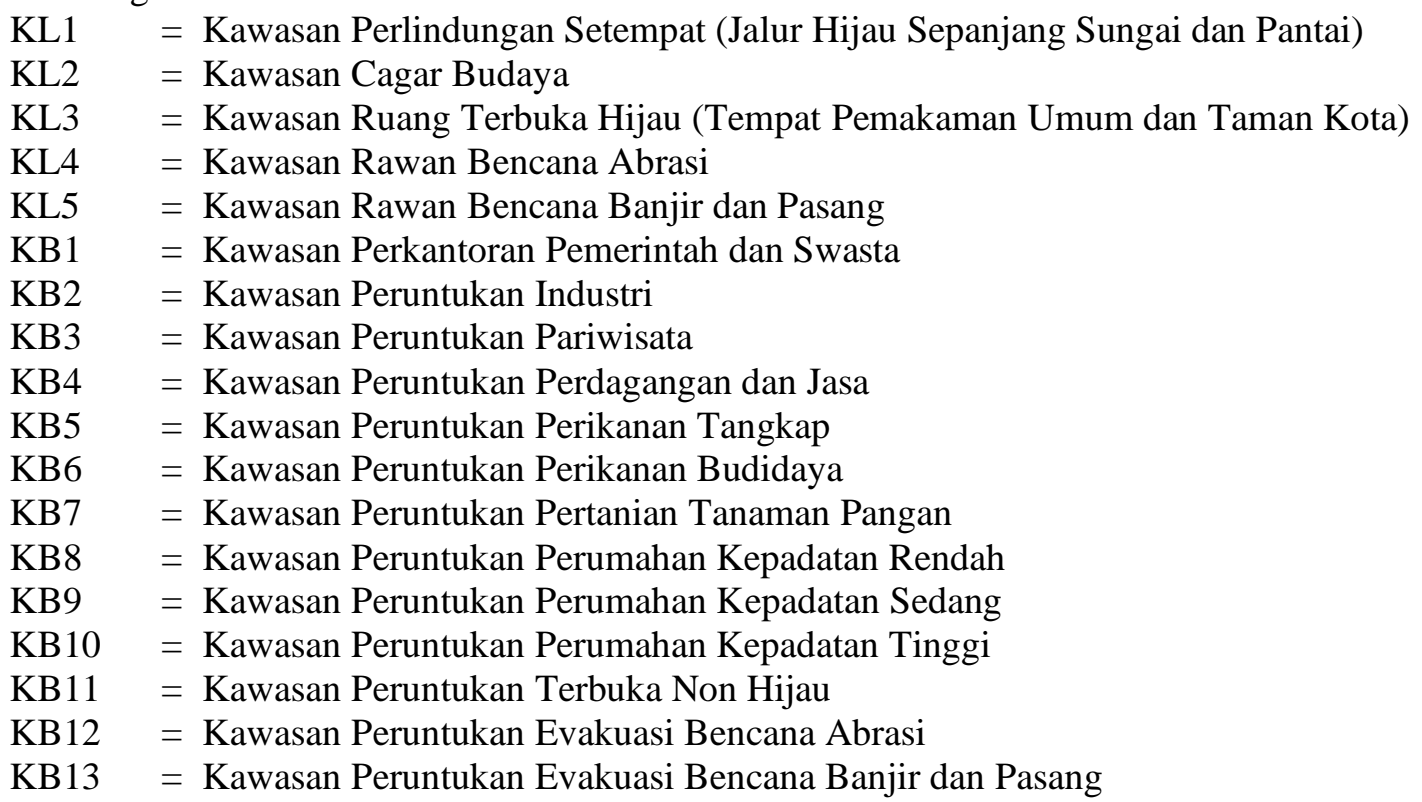

Berdasarkan grafik di atas, kawasan kawasan peruntukan perumahan kepadatan rendah, kawasan peruntukan perikanan budidaya, dan kawasan peruntukan tanaman pangan merupakan kawasan yang terkena dampak terbesar dari banjir pasang tahun 2020 apabila dibandingkan dengan wilayah lainnya dengan selisih luas terdampak yang cukup jauh. Padahal Kota Pekalongan merupakan simpul utama kawasan petanglong dengan sektor unggulan pertanian, pariwisata, industri dan perikanan. Hal tersebut jika dibiarkan tentu akan sangat merugikan dan menggangu aktivitas pertumbuhan perekonomian daerah pada sektor unggulan pertanian dan perikanan, sehingga permasalahan bencana banjir pasang harus segera diselesaikan dan penataan ruang di masa mendatang sangat perlu memperhatikan wilayah yang terkena banjir pasang.

\section{KESIMPULAN}

Tipe pasang surut di Kota Pekalongan adalah tipe campuran condong harian ganda dan ketinggian genangan banjir pasang pada tahun 2020 sebesar $54,28 \mathrm{~cm}$ dengan ketinggian tanah berkisar antara 0 hingga 12,74 meter sehingga didapat luasan genangan banjir pasang pada tahun 2020 sebesar 1.210,183 
hektar dengan nilai validasi RMSE sebesar 0,090. Banjir pasang tahun 2020 memberikan dampak hampir ke semua kawasan Rencana Pola Ruang Pemerintah Kota Pekalongan, kecuali kawasan peruntukan perumahan kepadatan tinggi dan kawasan cagar budaya. Kawasan-kawasan yang terkena dampak terbesar dari banjir pasang tahun 2020 adalah kawasan peruntukan perumahan kepadatan rendah, kawasan peruntukan perikanan budidaya, dan kawasan peruntukan pertanian tanaman pangan dengan luas terdampak berturut-turut sebesar 326,545 hektar, 310,907 hektar, dan 256,351 hektar.

\section{DAFTAR PUSTAKA}

Amin, C., Sukamdi, S., \& Rijanta, R. (2021). Exploring Migration Hold Factors in Climate Change Hazard-Prone Area using Grounded Theory Study: Evidence from Coastal Semarang, Indonesia. Sustainability, 13(8): 4335.

Anggito, A., \& Setiawan, J. (2018). Metodologi Penelitian Kualitatif. CV Jejak (Jejak Publisher). 268 hlm.

Atmodjo, W., \& Pranowo, W.S. (2019). Karakteristik Pasang Surut di Teluk Jakarta Berdasarkan Data 253 Bulan. Jurnal Riset Jakarta, 12(1): 25-36.

Badriyah, S.M., Mahmudah, S., \& Soemarmi, A. (2019). Leasing sebagai Alternatif Pembiayaan Kapal bagi Nelayan Kecil di Kota Pekalongan. Masalah-Masalah Hukum, 48(2): 204-214.

Effendi, R., Handoyo, G., \& Setiyono, H., (2017). Peramalan Pasang Surut di Sekitar Perairan Tempat Pelelangan Ikan (TPI) Banyutowo, Kabupaten Pati, Jawa Tengah. Journal of Oceanography, 6(1), pp.221-227.

Febriani, D.N., Helmi, M., \& Hariyadi, H. 2017. Kajian Genangan Banjir Pasang di Kecamatan Pekalongan Utara, Kota Pekalongan. Journal of Oceanography, 6(4): 579-587.

Guntara, O., Handoyo, G., \& Marwoto, J. (2017). Peramalan Pasang Surut Di Pelabuhan Perikanan Pantai Teluk Saleh Sumbawa. Journal of Oceanography, 6(4): 616-624.

Hakam, A. M., \& Harsasto, P. (2019). Evaluasi Proses Kebijakan Penanganan Banjir Pasang di Kota Semarang oleh Pemerintah Kota Semarang. Journal of Politic and Government Studies, $8(01)$ : 281-290.

Hasanudin, M., Kusmanto, E., \& Budisetyawan, W. (2016). Amplifikasi Pasang Surut dan Dampaknya Terhadap Perairan Pesisir Ppasangolinggo. OLDI (Oseanologi dan Limnologi di Indonesia), 1(3): 69-80.

Iskandar, S.A., Helmi, M., Muslim, M., Widada, S., \& Rochaddi, B. (2020). Analisis Geospasial Area Genangan Banjir Pasang dan Dampaknya pada Penggunaan Lahan Tahun 2020-2025 di Kota Pekalongan Provinsi Jawa Tengah. Indonesian Journal of Oceanography, 2(3): 73-84.

Jazuli, A. (2017). Penegakan Hukum Penataan Ruang dalam Rangka Mewujudkan Pembangunan Berkelanjutan. Jurnal Rechts Vinding: Media Pembinaan Hukum Nasional, 6(2): 263-282.

Marfai, M.A., Mardiatno, D., Cahyadi, A., Nucifera, F., \& Prihanto, H. (2013). Pemodelan Spasial Bahaya Banjir Pasang Berdasarkan Skenario Perubahan Iklim dan Dampaknya di Pesisir Pekalongan. Bumi Lestari Journal of Environment, 13(2), 244- 256.

Nurhendro, R.H., \& Marfai, M.A., (2016). Pemodelan dan Analisis Dampak Banjir Pesisir Surabaya Akibat Kenaikan Air Laut Menggunakan Sistem Informasi Geografis. Jurnal Bumi Indonesia, 5(4), pp.1-7.

Prayogo, L.M. (2021). Metode Kuadrat Terkecil untuk Analisis Konstanta Harmonik Pasang Surut Air Laut di Pulau Gili Raja, Kabupaten Sumenep, Madura. Pena Akuatika: Jurnal Ilmiah Perikanan dan Kelautan, 20(1): 72-79.

Priyono, B., (2016). Perizinan Sebagai Sarana Pengendalian Penataan Ruang dalam Perspektif Pemanfaatan Ruang di Daerah. Jurnal Administrasi Pemerintahan Daerah, 8: 16-37.

Romadhon, Y.A. (2017). Kebijakan Pengelolaan Air Limbah dalam Penanganan Limbah Batik di Kota Pekalongan. Insignia: Journal of International Relations, 4(02): 49-64.

Rukajat, A. (2018). Pendekatan Penelitian Kuantitatif: Quantitative Research Approach. Deepublish. $160 \mathrm{hlm}$.

Salim, M. A. (2018). Penanganan Banjir dan Pasang di Wilayah Pekalongan. Jurnal Teknik Sipil, 11: 18. 
Sepúlveda, C., Rivera, A., Gelcich, S., \& Stotz, W.B. (2019). Exploring Determinants for The Implementation of Mixed TURF-Aquaculture Systems. Science of The Total Environment, 682: 310-317.

Setyati, W.A., Rezagama, A., Agustini, T.W., Hidayat, Y., Wishnu, N.P., \& Wulandary, D.A. (2018). Inovasi Penanganan Mitigasi Bencana Desa Bedono Kecamatan Sayung Demak Akibat Efek Abrasi. SNKPPM, 1(1): 198-200.

Sunu, H. A., Yuwono B.D., \& Suprayogi A. (2019). Analisis Ketelitian DSM Kota Semarang dengan Metode InSAR Menggunakan Citra Sentinel-1. Jurnal Geodesi Undip, 8(3): 17-26.

Syamsudin, S., Kushadiwijayanto, A.A., \& Risko, R. (2019). Studi Batimetri dan Pasang Surut Di Kawasan Perairan Batu Burung Kota Singkawang Selatan Kalimantan Barat. Jurnal Laut Khatulistiwa, 2(3): 144-150.

Yuniastuti, E. (2016). Identifikasi Tipologi dan Dinamika, Potensi dan Permasalahan, dan Strategi Pengelolaan Wilayah Kepesisiran di Wilayah Kepesisiran Demak. Jurnal Geografi, 8(1): 3146.

Zuhaira, H., Handoyo, G., Purwanto, P., Suryoputro, A.A.D., \& Yulina, S. (2020). Kajian Perbandingan Analisis Pasang Surut dengan Menggunakan Metode Least Square dan Fourier di Perairan Barat Sumatera. Indonesian Journal of Oceanography, 2(3): 27-34. 